\title{
The influence of spring grazing management on yield and water use of rainfed lucerne
}

\author{
Richard E. SIM ${ }^{1, *}$ and Derrick J. MOOT ${ }^{2}$ \\ ${ }^{1} P G G$ Wrightson Seeds Ltd, Kimihia Research Centre, Lincoln 7676, New Zealand \\ ${ }^{2}$ Field Research Centre, Faculty of Agriculture and Life Sciences, PO Box 85804, Lincoln University, Lincoln \\ 7647, Christchurch, New Zealand \\ *Corresponding author: rsim@pggwrightsonseeds.co.nz
}

\begin{abstract}
Flexible spring grazing management can increase the use of lucerne on farms. However, the negative impacts of set stocking on the survival of plants usually preclude its use. In this experiment, crops of 'Stamina 5' lucerne at Ashley Dene, Lincoln University were rotationally grazed, semi-set stocked or set stocked from September to December 2011. Dry matter (DM) yield to December was $6.3 \mathrm{t} \mathrm{DM} / \mathrm{ha}$, and consistent among crops. However, the larger leaf area of the semi-set- and set-stocked crops intercepted $45 \%$ more solar radiation and transpired $25 \%$ more water than the rotationally grazed crop. The set-stocked regime had a lower efficiency of resource use. This was probably due to greater respiration and/or partitioning of DM to the root mass. Set-stock regimes required continual initiation of new shoots from basal buds, which remobilised and, therefore depleted, stored assimilates. To minimise this impact, farmers should maintain a canopy cover of 2 to $2.5 \mathrm{t} \mathrm{DM} / \mathrm{ha}(\sim 20 \mathrm{~cm}$ tall $)$ on any set-stocked lucerne. This will maximise radiation interception and compensate for reserve losses. In the study year, grazing management did not influence feed supply through the manipulation of water use because soil evaporation losses were inversely related to crop water use. Consequently, total water use was consistent among crops, with higher soil evaporation from frequent rewetting of the soil for rotationally grazed crops. For farmers, these results suggest continuous grazing of lucerne is possible, but it should be managed to maintain full canopy cover and minimise reserve depletion that will reduce DM yields and stand persistence.
\end{abstract}

Keywords: Alfalfa, Medicago sativa L., rotational grazing, radiation-use efficiency, respiration, set stocked, water-use efficiency

\section{Introduction}

The integration of lucerne (Medicago sativa L.) on farm is one strategy that can be used to increase farm productivity and resilience under water-limited conditions (Avery et al. 2008; Moot 2014; Moot et al. 2019). On these farms, water stress develops most summers and pasture production declines when about half of the soil-stored plant-available water is depleted (Mills et al. 2006; Sheaffer et al. 1988). Lucerne extracts water from deep soil layers (Brown et al. 2005; Sim et al. 2017), which enables it to maintain plant growth during these periods and produce large quantities of high-quality forage, relative to shallower rooted species. Rainfed lucerne often provides twothirds of its total dry matter (DM) in spring, particularly in areas with highly variable, alluvial outwash soils (Sim et al. 2015).

Matching lucerne feed supply in spring with animal demand has been perceived as difficult by some farmers in the past (Kirsopp 2001), who consigned lucerne to 'cut and carry' systems (Moot et al. 2019). This was particularly apparent in late spring when high lucerne growth rates create an illusion of feed surpluses to conserve. However, as little as one month later, the lucerne crop can exhaust the plant-available soil moisture and, consequently, growth ceases so feed demand exceeds supply.

To encourage greater direct feeding of lucerne to ewes and lambs, more flexible grazing management guidelines were developed (Moot et al. 2003). These include a recommendation that lucerne should not be grazed from July until mid-September or until crops are at least $15 \mathrm{~cm}$ tall (Moot et al. 2003; Moot et al. 2016). Consequently, farmers who rely on lucerne for a large (30-40\%) proportion of their spring feed often lamb two to three weeks later compared with those on grass-based pastures (Kirsopp 2001; Moot 2012). The perception is that this later lambing reduces the number of early lambs for sale and increases the risk of lower sale weights if there is an early summer dry. However, over 30 years ago, White (1982) suggested stock performance is maximised when $40-60 \%$ of the farm is under lucerne. More recently, Avery et al. (2008) implemented this through transformational change to their farm system. For farmers to realise the full benefits of larger areas of lucerne, more flexible spring grazing management is needed. This requires understanding of lucerne physiology (Moot et al. 2003), particularly in relation to crop water use and lucerne shoot production, to ensure herbage production and stand persistence are not compromised.

The duration of spring growth depends on available soil water. Crop water use is the amount of this water extracted for transpiration which is driven by weather 
variables (Monteith 1965) and the crop canopy (French \& Legg 1979). The canopy intercepts incoming solar radiation which supplies the radiant energy to drive evaporation from the leaf surface. It is possible that canopy cover manipulation can provide grazing flexibility by influencing the time of crop water use and the temporal pattern of DM production.

Currently, optimal grazing management is welldefined for rotationally grazed systems (Moot et al. 2003; Moot et al. 2016) and increased grazing frequency is known to reduce the amount of solar radiation intercepted which reduces yield proportionally (Teixeira et al. 2007). Continuous grazing (set stocking) of lucerne has not been recommended due to increased plant mortality, subsequent weed ingress and decreased stand persistence (Palmer 1982; Moot et al. 2003). Stock also selectively graze the leaf and soft stem fractions of lucerne first, which removes apices. This interrupts growth, so new basal shoots then deplete stored assimilates through remobilisation from the taproot and crown (Avice et al. 1996). As grazing pressure increases, these new shoots are removed before full expansion, and their contribution to crop canopy and radiation interception rapidly declines. As a consequence, decreased yields of up to $75 \%$ are reported in set stocked compared with rotationally grazed stands (Janson 1974; Janson 1982; O'Connor 1970). Thus, stocking rate and grazing duration are key factors to consider in any new grazing strategy.

Based on understanding lucerne growth and development, a potential continuous grazing regime may be to set stock lucerne at a rate that maintains canopy cover to allow the expansion of new shoots from basal buds. This approach would maintain the interception of radiation and reduce the burden on stored assimilates. In a dryland Canterbury environment, a grazing duration of $\sim 3$ months is available from spring until the onset of drought in early December. Then the crop is usually destocked, and autumn regrowth is grazed on a longer rotation to allow replenishment of perennial reserves (Moot et al. 2003).

Therefore, the primary objective of this research was to quantify crop canopy cover and relate this to solar radiation interception and water use. To do this, crops were subjected to three grazing strategies: (i) rotational; (ii) set stocking; and (iii) semi-set stocking. The aim was to examine if the time of DM production was influenced by grazing the crop at different times, through the manipulation of crop water use.

\section{Materials and Methods \\ Experimental site}

Two adjacent experiments were conducted using rainfed lucerne ('Stamina 5', fall dormancy 5), at Ashley Dene Research Farm in paddock H7 (43⒊' S, $172^{\circ} 19^{\prime}$ E, 35 m.a.s.1). Measurements were taken from July 2011 to June 2012 on lucerne crops in their third year under different spring grazing managements. These were rotational, set stocked or semi-set stocked with twin-bearing ewes during the lactation phase. Time of grazing was used to manipulate the pattern of canopy development and leaf area to determine how this influenced DM yield and crop water use.

The soil is a Lowcliffe stony silt loam (Cox 1978). This type of soil has a shallow topsoil of $0.25-0.35 \mathrm{~m}$ containing about $10 \%$ stones, by volume, overlaying horizons of sandy loams with a stone content up to $45 \%$ (Di \& Cameron 2002). As a consequence, established lucerne can extract $240 \mathrm{~mm}$ of plant-available water to a depth of $2.3 \mathrm{~m}$ (Sim et al. 2017).

In November 2008, lucerne seed inoculated with Sinorhizobium meliloti rhizobia was sown at $10.5 \mathrm{~kg} /$ ha (bare seed equivalent) using an Øyjord cone seeder in two experimental areas which covered 4.2 ha. These experiments were part of a wider study that evaluated seven lucerne cultivars over five years when subjected to different grazing managements as reported by Mills et al. (2016) and Moot et al. (2016). Experiment 1 established a rotational grazing system based on six 0.43 ha $(49 \times 89 \mathrm{~m})$ paddocks. Each paddock contained seven lucerne cultivar sub plots $(6.3 \times 24.5 \mathrm{~m})$ in a randomised complete block design, replicated four times, however only two replicates were measured in this study. In the same area, Experiment 2 was established as a split-plot within a randomised complete block design. The main plots $(0.43 \mathrm{ha})$ were two grazing treatments - set stocked and semi-set stocked, and the sub plots consisted of three lucerne cultivars, replicated four times. This research focussed on sub plots sown in 'Stamina 5' that were subjected to the same grazing durations. This meant in the rotationally grazed experiment, only data from Paddock 1 were compared with the set stocked and semi-set stocked treatments.

\section{Agronomic and grazing management}

Chemical analysis of the topsoil $(0-75 \mathrm{~mm})$ prior to the start of the measurement period showed that; $\mathrm{pH}=5.8$, Olsen $\mathrm{P}=16 \mathrm{mg} / \mathrm{kg}, \mathrm{K}=0.48 \mathrm{mg} / \mathrm{kg}$ and sulphate sulphur $=11 \mathrm{mg} / \mathrm{kg}$. Lime $(2.8 \mathrm{t} / \mathrm{ha})$ and 500 $\mathrm{kg} /$ ha sulphur super 15 (8\% P; $15 \% \mathrm{~S})$ were applied in September 2011.

Grazing commenced on 27 September 2011 for all treatments. It finished on 5 December 2011 when lucerne herbage mass decreased to $\sim 500 \mathrm{~kg} \mathrm{DM} / \mathrm{ha}$ and feed supply was well below animal demand. The rotational grazing system was first imposed in Paddock 1 with twin-bearing ewes at an equivalent stocking rate of 12 ewes/ha. The ewes and lambs were rotated around Paddocks 1 to 6 two times. Stock grazed each paddock for 5 to 7 days, which created about a 35- to 42-day 
rotation before the regrowth in the same paddock was grazed again. The stocking rate of the set-stocked and semi-set stocked treatments was 14 twin-bearing ewes/ ha for the duration of the grazing period. The set-stocked grazing treatment consisted of leaving the grazing sheep in the sub plot for the entire period. The semiset stocked grazing treatment involved alternatively grazing each half of the sub plot every 10 days.

\section{Measurements and calculations Environmental data}

Meteorological data (rainfall and temperature) were recorded from an on-farm weather station, located $0.5 \mathrm{~km}$ from the experimental site. Solar radiation and Penman potential evapotranspiration $\left(\mathrm{P}_{\mathrm{ET}}\right)$ were measured at Broadfields Meteorological Station (NIWA, National Institute of Water and Atmosphere Research, New Zealand) which is located $11 \mathrm{~km} \mathrm{NE}$ of the experimental site. Rainfall for the grazing period (September to December) was $170 \mathrm{~mm}, 20 \%$ greater than the long-term mean of $140 \mathrm{~mm}$ for this period. $\mathrm{P}_{\mathrm{ET}}$ for the same period was $355 \mathrm{~mm}$ compared with the long-term mean of 320 $\mathrm{mm}$. Total annual rainfall and $\mathrm{P}_{\mathrm{ET}}$ (1 July 2011 to 30 June 2012) was $645 \mathrm{~mm}$ and $1085 \mathrm{~mm}$, respectively, which is consistent with the long-term means. Solar radiation and air temperature followed the expected seasonal patterns.

\section{Shoot biomass and crop height}

Shoot biomass was measured using a single $0.2 \mathrm{~m}^{2}$ quadrat per plot, cut just above crown height $(\sim 50 \mathrm{~mm})$. Measurements were taken systematically throughout the season to avoid re-cutting previously sampled areas. All samples were dried in a forced air oven $\left(60^{\circ} \mathrm{C}\right)$ to a constant weight. Shoot biomass of set-stocked and semi-set stocked plots were measured using $0.7 \times 1.1$ $\mathrm{m}$ exclusion cages within which a $0.2 \mathrm{~m}^{2}$ quadrat was sampled. Cages were placed within plots and cuts taken from the excluded area and surrounding plot every 10 days. Cages were then moved to a new area. The amount of DM grown for the 10-day period was the difference between the DM yield from the cage and the pre-grazing cut 10 days earlier. Under the continuous grazing regimes, the swards became a mixture of: complete shoots, through a continuum of shoots with decreasing proportions of leaf to bare stems; and senesced material that had been trampled by the grazing stock. Therefore, DM samples were separated into green and senesced $(<50 \%$ green) material, with the latter discarded to prevent the higher DM\% material influencing yield. This separation was also important to accurately quantify leaf area index. Shoot biomass was measured beyond the spring grazing period, until June 2012 to quantify total annual yield. Crop height $(\mathrm{cm})$ was measured from the average height of the tallest stems from the quadrat used to measure shoot biomass.

\section{Leaf area index and radiation interception}

Leaf area index (LAI; $\mathrm{m}^{2}$ leaf $/ \mathrm{m}^{2}$ soil) was calculated from destructive green area index (GAI) measurements from a sub-sample of 20 shoots passed through a belt area meter (LICOR 3100, Licor Inc. Lincoln, USA). Samples were taken from the quadrat used to measure biomass and only those stems with $>50 \%$ green leaf were considered to contribute to photosynthesis were measured. Shoot samples were dried in a forced air oven $\left(60^{\circ} \mathrm{C}\right)$ to a constant weight and GAI was calculated using specific leaf weight (SLW; g DM m² GAI). GAI was multiplied by a factor of 1.30 to convert to LAI determined from a calibration process (Sim et al. 2017).

The fractional solar radiation intercepted by the canopy was calculated as a function of LAI and canopy architecture $(k)$ using the Beer-Lambert law which describes the exponential reduction of light through the canopy (Sinclair 2006). During the spring growth period, these crops achieved $95 \%$ light interception, or the critical LAI at 3.2. As a result, $k$ for these crops was 0.94 (Sim et al. 2017). Daily intercepted radiation (MJ/ $\mathrm{m}^{2}$ ) was calculated from interpolated LAI from fitted logistic curves that described the shape of leaf area over time.

\section{Soil water content and crop water use}

Volumetric soil water content was measured at 10 - to 14-day intervals in 22 layers of the soil to a depth of $2.3 \mathrm{~m}$. The top layer $(0-0.2 \mathrm{~m})$ was measured with a time domain reflectometer (TDR; Trase System, Soilmoisture Equipment Corp., CA, USA) and the remaining layers were measured at their mid-point using a neutron probe (Troxler Electronics Industries Inc., USA). The soil water balance accounted for rainfall, change in measured soil water content to $2.3 \mathrm{~m}$ depth and drainage. Evapotranspiration was partitioned into soil evaporation $\left(E_{s}\right)$ and crop water use, or transpiration, $(T)$ as is extensively detailed in Sim et al. (2017). Water-use efficiency (WUE; kg DM/ $\mathrm{ha} / \mathrm{mm}$ ) was calculated from the slope of the linear regression of accumulated shoot DM and crop water use (transpiration) over the same period.

\section{Statistical analysis}

All statistical analyse were conducted in Genstat (version 14.1) (Lawes Agricultural Trust, IACR, Rothamsted, UK). Data from Experiments 1 (two replicates) and 2 (four replicates) were subjected to an unbalanced one-way analysis of variance (ANOVA) with grazing method as the main effects factor. Differences among grazing treatment means were identified by Fisher's protected 1.s.d $(\alpha=0.05)$ where the ANOVA identified a significant effect $(\mathrm{P} \leq 0.05)$. Linear regressions were calculated using the leastsquares regression method. 


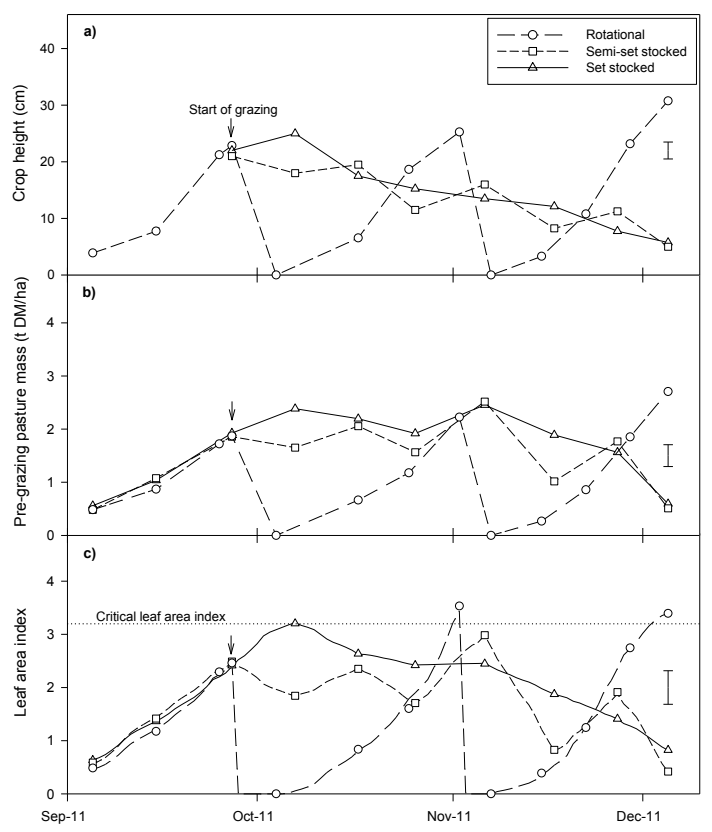

Figure 1 Pre-grazing pasture height (a), mass (b) and leaf area index (c) of rainfed lucerne subjected to three grazing managements from 27 September to 5 December 2011 at Lincoln University, New Zealand. Note: Bar represents I.s.d $(P=0.05)$. Critical leaf area index determined for these crops (from Sim et al. 2017).

\section{Results \\ DM Yield}

Accumulated spring DM yield to December was $6.3 \mathrm{t}$ $\mathrm{DM} /$ ha with a trend $(\mathrm{P}=0.067)$ that favoured rotational grazing (Table 1). By the end of the season in June 2012 , the annual yield was greatest $(\mathrm{P}=0.01)$ under rotational grazing at $12.1 \mathrm{t} \mathrm{DM} / \mathrm{ha}$, compared with 10.6 $\mathrm{t} \mathrm{DM} /$ ha from the set stocked and $10.5 \mathrm{t} \mathrm{DM} /$ ha from semi-set-stocked treatments.

Table 1 Accumulated DM yield ( $\mathrm{DM} / \mathrm{ha}$ ) of rainfed lucerne from 8 June 2011 to 5 December 2011 (Spring DM) and then in total to 13 June 2012 when subjected to three grazing managements at Ashley Dene, Lincoln University, New Zealand.

\begin{tabular}{lcc}
\hline Grazing treatment & Spring DM & Total DM ${ }^{1}$ \\
\hline Set-stocked & 6.1 & $10.6 \mathrm{~b}$ \\
Semi-set-stocked & 5.9 & $10.5 \mathrm{~b}$ \\
Rotational & 6.8 & $12.1 \mathrm{a}$ \\
Mean & 6.3 & 11.1 \\
P & 0.067 & 0.010 \\
SEM & $\mathrm{ns}$ & 0.33 \\
\hline
\end{tabular}

\footnotetext{
${ }^{1}$ Means followed by the same letter are not different at the $\alpha=0.05$ level.
}

Pre-grazing pasture height, mass and crop canopy

The pre-grazing pasture height was $22 \mathrm{~cm}$ (Figure 1a), mass was $1.9 \mathrm{t} \mathrm{DM} /$ ha (Figure 1b) and LAI was 2.4 (Figure 1c) for all treatments when grazing commenced on 27 September 2011. Under rotational grazing, there were three growth cycles. The regrowth duration shortened from 36 to 28 days and the pre-grazing pasture mass increased from 2.2 to $2.7 \mathrm{t} \mathrm{DM} /$ ha for the second and third regrowth rotations, respectively. Pasture cover continued to be maintained for both the set- and semi-set-stocked treatments and reached a maximum of $2.6 \mathrm{t} \mathrm{DM} / \mathrm{ha}$ on the 6 November. For the set-stocked crop, crop height and LAI reached a maximum on the 7 October of $25 \mathrm{~cm}$ and 3.2, respectively which indicated canopy closure. LAI then decreased to 0.7 by the 5 December. Rotationally grazed crops reached canopy closure with an LAI of 3.5 in Regrowth Cycles 2 and 3. After this, crop height and $\mathrm{DM}$ cover decreased to $5 \mathrm{~cm}$ and $0.5 \mathrm{t} \mathrm{DM} / \mathrm{ha}$, respectively by 5 December when all treatments were destocked.

\section{Radiation interception}

The rotationally grazed crop intercepted $950 \mathrm{MJ} / \mathrm{m}^{2}$ of total solar radiation from 8 June to 5 December, or $30 \%$ less $(\mathrm{P}<0.05)$ than the set and semi-set stocked crops which intercepted $1400 \mathrm{MJ} / \mathrm{m}^{2}$ (Figure 2). The slope of the regression of accumulated intercepted radiation against accumulated DM is the crop radiation use efficiency (RUE). This was $0.73 \mathrm{~g} \mathrm{DM} /$ $\mathrm{MJ}$, and consistent for all treatments until the grazing commenced on 27 September. RUE for the rotationally grazed crop remained at this level, but RUE for both the set and semi-set stocked crops decreased to $0.37 \mathrm{~g} \mathrm{DM} /$ MJ, or $50 \%$ less.

\section{Soil water and crop water use}

Crop water use was $290 \mathrm{~mm}$ in the set- and semiset stocked crops, 25\% higher $(\mathrm{P}=0.047)$ than the rotationally grazed crops (Table 2). However, rotationally grazed crops experienced $128 \mathrm{~mm}$ of soil water evaporation compared with $77 \mathrm{~mm}$ for the other crops. Therefore, total water use was $364 \mathrm{~mm}$, and consistent $(\mathrm{P}=0.896)$ among treatments. Accumulated WU in relation to DM up to 5 December 2011 displayed a constant linear relationship $\left(\mathrm{R}^{2}>0.98\right.$; data not shown; Sim 2014). WUE was $21.3 \mathrm{~kg} \mathrm{DM} / \mathrm{ha} / \mathrm{mm}$ for the set and semi-set stocked crops which was lower $(\mathrm{P}=0.033)$ than the $30.5 \mathrm{~kg} \mathrm{DM} / \mathrm{ha} / \mathrm{mm}$ in the rotationally grazed crop.

\section{Discussion}

The ability to continuously graze lucerne in early spring when farmers set stock ewes for lambing would increase the flexibility of crops and encourage 


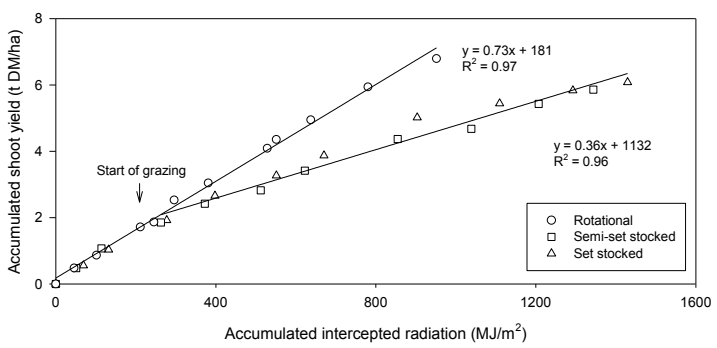

Figure 2 Relationship between accumulated shoot yield and accumulated total intercepted radiation of rainfed lucerne from 8 June to 5 December 2011 subjected to three grazing management treatments at Lincoln University, New Zealand.

greater direct feeding. In our study, spring herbage yields were $6.3 \mathrm{t} \mathrm{DM} / \mathrm{ha}$ and consistent among grazing management strategies (Table 1). We aimed to maintain a full canopy throughout the duration of the grazing period. This approach succeeded in maximising DM yield for continuously grazed lucerne. The implication is that stocking rate is the critical management decision when set stocking. Lucerne should only be stocked at a rate that maintains a crop canopy cover of at least $2-2.5 \mathrm{t} \mathrm{DM} / \mathrm{ha}$ (Figure 1b), or $20-25 \mathrm{~cm}$ tall (Figure 1a). This regime allowed newly initiated shoots to expand to maintain a LAI of $\sim 3.2$ (Figure 1c) where they contributed to photosynthesis as $95 \%$ of incoming solar radiation was intercepted (Sim et al. 2017). This recommendation differs from those generated by earlier experiments where continuously grazed crops were stocked at rates up to twice that of the carrying capacity of rotationally grazed crops (Janson 1974; Janson 1982; O'Connor 1970). The effect of these higher rates was the stock quickly grazed the newly initiated shoots and the crop canopy rapidly collapsed. Consequently, the continuously grazed lucerne crops in those earlier experiments yielded as much as $75 \%$ less

Table 2 Crop water use (T; mm), water use efficiency (WUE; $\mathrm{kg} \mathrm{DM} / \mathrm{ha} / \mathrm{mm})$ and soil evaporation $\left(E_{S} ; \mathrm{mm}\right)$ of rainfed lucerne from 8 June 2011 to 5 December 2011 subjected to three grazing managements at Ashley Dene, Lincoln University, New Zealand.

\begin{tabular}{lcccc}
\hline Grazing treatment & $\mathbf{T}$ & WUE & $\mathbf{E}_{\mathbf{S}}$ & Total WU \\
\hline Set stocked & $297 \mathrm{a}$ & $21.6 \mathrm{~b}$ & $77 \mathrm{~b}$ & 374 \\
Semi-set stocked & $282 \mathrm{a}$ & $20.9 \mathrm{~b}$ & $76 \mathrm{~b}$ & 358 \\
Rotational & $231 \mathrm{~b}$ & $30.5 \mathrm{a}$ & $128 \mathrm{a}$ & 359 \\
Mean & 270 & 24.3 & 94 & 364 \\
P & 0.047 & 0.033 & 0.032 & 0.896 \\
SEM & 10.6 & 1.43 & 7.96 & $\mathrm{~ns}$ \\
\hline
\end{tabular}

Note: Means within a column followed by the same letter are not different at the $a=0.05$ level. than rotationally grazed crops.

The period of any set-stocked lucerne should be minimised in early spring or DM yields will be compromised. This limitation was evident in the current study as, by the end of the season, the annual yield was $10.6 \mathrm{t} \mathrm{DM} /$ ha for continuously grazed crops compared with $12.1 \mathrm{t} \mathrm{DM} /$ ha under rotational grazing (Table 1). The decline in yield of continuously grazed crops was due to lower efficiency in their conversion of solar radiation to shoot biomass. Specifically, the RUE of these crops was $0.37 \mathrm{~g} \mathrm{DM} / \mathrm{MJ}$, or $50 \%$ less than in the rotationally grazed lucerne (Figure 2). Dynamic RUE values for lucerne have been extensively documented, but this is the first value reported for continuously grazed crops. This value is consistent with lucerne crops that preferentially partition biomass to the perennial reserves, such as in autumn (Brown et al. 2006) or during their establishment phase (Sim 2014; Teixeira et al. 2011).

The hypothesis for continuously grazed crops is that the incomplete canopy allowed sunlight to pass through the leaves and into the underlying layers. This situation increased the red to far-red (R: FR) ratio perceived by the plant crown and as a result, it induced new basal shoots to develop (Peri 2002). This constant renewal of basal buds requires the remobilisation of assimilates stored within the taproot and crown, which imposes greater respiration costs to the plant (Avice et al. 1996). The grazing duration was 70 days in the current experiment, which was probably too long to be recommended on farm. The consequence was the total yield was $1.5 \mathrm{t} \mathrm{DM} /$ ha lower for continuously grazed crops than for rotational grazing (Table 1). The lower total herbage yield of continuously grazed crops also corresponds to an additional $1.3 \mathrm{t} \mathrm{DM} / \mathrm{ha}$ required to replenish the perennial reserves in the autumn. Root sampling of the crops in the current study by Speedy (2012) in November 2011 showed perennial DM (crown $+300 \mathrm{~mm}$ taproot) was $4.7 \mathrm{t} \mathrm{DM} / \mathrm{ha}$ for rotationally grazed crops compared with set stocked and semi-set stocked crops which had 3.4 t DM/ha $(\mathrm{P}=0.006)$. By May 2012, the perennial DM was 6.1 t DM/ha and consistent among all crops $(\mathrm{P}=0.149)$. The implication for farmers is the need to destock crops in late summer and autumn to allow the replenishment of root reserves (Moot et al. 2003), particularly for paddocks that have been continuously grazed in spring.

A more appropriate set stocking duration is probably about four to six weeks at a stocking rate that maintains the crop canopy close to full, over one lambing cycle. In the current study this was no more than 12 ewes/ ha. This grazing duration is equivalent of one grazing round of a six-paddock rotation (Moot et al. 2003). For farmers, this could mean lucerne could be lightly set stocked about two weeks before lambing and left 
undisturbed for lambing. This regime would overcome one of the main perceived disadvantages of direct feeding lucerne in spring.

A second hypothesis associated with the decrease in RUE under continuous grazing is the removal of upper canopy layers by selective grazing resulted in the lower leaves intercepting most of the incoming solar radiation. Lower layers of the canopy contain older leaves with lower nitrogen $(\mathrm{N})$ content that are less efficient at photosynthesis than younger leaves (Lemaire et al. 1991). Crop photosynthetic capacity is closely linked to leaf $\mathrm{N}$ content as $50 \%$ of the soluble protein in $\mathrm{C}_{3}$ leaves can be made up of Rubisco, the principle enzyme responsible for carbon dioxide $\left(\mathrm{CO}_{2}\right)$ fixation (Sinclair \& Horie 1989). However, in the present study, crop $\mathrm{N}$ uptake showed a strong linear increase in relation to LAI with an $\mathrm{R}^{2}$ of 0.88 which was unaffected $(\mathrm{P}=0.36)$ by grazing treatment (Sim 2014). A constant N uptake of $31 \mathrm{~kg} \mathrm{~N}$ per unit of LAI was estimated and leaf $\mathrm{N}$ was consistently above the critical threshold for maximum leaf area expansion presented by Lemaire et al. (2007). Therefore, leaf photosynthetic capacity would not be expected to be compromised in this study. However, when perennial reserves are exhausted through extended set stocking or from not being replenished in autumn, inadequate $\mathrm{N}$ supply would be expected to reduced leaf area expansion, radiation interception and, therefore, yield.

In the year studied, grazing management did not influence feed supply through the manipulation of water use because evaporation $\left(\mathrm{E}_{\mathrm{S}}\right)$ losses was inversely related to soil crop water use. Consequently, total water use was $364 \mathrm{~mm}$ and was consistent among all crops (Table 2). This was because of the relatively even distribution of rainfall in this environment and the higher than average spring rainfall which maintained the water content of the upper soil layer above the lower threshold for $\mathrm{E}_{\mathrm{S}}$ for the grazing period. Therefore, if $\mathrm{E}_{\mathrm{S}}$ was reduced and more water was used via transpiration then yield gains could be made. This situation may occur in a drier climate where the soil surface is dry for extended periods which was recently shown for wheat by Harrison et al. (2011). Alternatively, there may be opportunities to manipulate crop water use through grazing management when lucerne is grown on a deeper soil and stored water contributes to a greater proportion of total water use. For farmers in waterlimited environments, this information emphasises the need to minimise non-productive water losses such as transpiration by weeds. This knowledge is more applicable with increased defoliation frequency or set stocking, which lengthens the time the canopy is incomplete and allows germination of weed seeds. Competition for resources from weeds will decrease the water available for lucerne and will reduce stand persistence in the longer term (Palmer 1982).

\section{Conclusions}

Continuously grazing lucerne offers farmers greater flexibility for spring grazing management provided:

1. Stock enter when the crop herbage mass is $10 \mathrm{~cm}$.

2 . The crop canopy can expand to a height of at least $20-25 \mathrm{~cm}$. This process maximises solar radiation interception to compensate for lower efficiency of resource use, due to greater remobilisation of stored assimilates.

3. Crops are only continuously grazed for a short period in the spring. This is probably 4-6 weeks, or one grazing round of a six-paddock rotation.

\section{ACKNOWLEDGEMENTS}

The William Machin Trust funded Richard Sim's Ph.D. research, and Beef + Lamb NZ through the P21 Phase II and "Which Legume where?" programmes funded the grazing experiment and write-up.

\section{REFERENCES}

Avice JC, Ourry A, Lemaire G, Boucaud J. 1996. Nitrogen and carbon flows estimated by $15 \mathrm{~N}$ and $13 \mathrm{C}$ pulse-chase labelling during regrowth of alfalfa. Plant Physiology 112: 281-290.

Avery D, Avery F, Ogle IG, Wills BJ, Moot DJ. 2008. Adapting farm systems to a drier future. Journal Proceedings of the New Zealand Grassland Association 70: 13-18.

Brown HE, Moot DJ, Pollock KM. 2005. Herbage production, persistence, nutritive characteristics and water use of perennial forages over 6 years on a Wakanui soil loam. New Zealand Journal of Agricultural Research 48: 423-439.

Brown HE, Moot, DJ, Teixeira EI. 2006. Radiation use efficiency and biomass partitioning of lucerne (Medicago sativa) in a temperate climate. European Journal of Agronomy 25: 319-327.

Cox JE. 1978. Soils and agriculture of part Paparua County, Canterbury, New Zealand. New Zealand Soil Bureau Bulletin 34. DSIR, Wellington.

Di HJ, Cameron KC. 2002. Nitrate leaching and pasture production from different nitrogen sources on a shallow stoney soil under flood irrigation dairy pasture. Australian Journal of Agricultural Research 40: 317-334.

French BK, Legg BJ. 1979. Rothamsted irrigation 1964-76. Journal of Agricultural Science, U.K., 92: 15-37.

Harrison MT, Evans JR, Dove H, Moore AD. 2011. Recovery dynamics of rainfed winter wheat after livestock grazing 1. Growth rates, grain yields, soil water use and water-use efficiency. Crop and Pasture Science 62: 947-959.

Janson CG. 1982. Lucerne grazing management research. In: Wynn-Williams RB. Ed. Lucerne for the 
80 's. Agronomy Society of New Zealand: Palmerston North, pp. 85-90

Janson CG. 1974. Lucerne management for the critical spring period under light land grazing. Proceedings of the New Zealand Grassland Association 36: 6677.

Kirsopp S. 2001. Management techniques to maximise legume production in dryland farming., Masters of Applied Science thesis, Lincoln University, Canterbury, New Zealand. http://hdl.handle. net/10182/2595

Lemaire G, Onillon B, Gosse G, Chartier M, Allirand JM. 1991. Nitrogen distribution within a lucerne canopy during regrowth: relation with light distribution. Annals of Botany 68: 483-488.

Lemaire G, van Oosterom E, Sheehy J, Jeuffroy M, Massignam A, Rossato L. 2007. Is crop N demand more closely related to dry matter accumulation of leaf area expansion during vegetative growth? Field Crops Research 100: 91-106.

Mills AM, Moot DJ, McKenzie BA. 2006. Cocksfoot pasture production in relation to environmental variables. Proceedings of the New Zealand Grassland Association 68: 89-94.

Mills AM, Smith MC, Moot DJ. 2016. Relationships between dry matter yield and height of rotationally grazed dryland lucerne. Journal of New Zealand Grasslands 78: 185-196.

Monteith JL. 1965. Evaporation and environment. In Fogg GE. Ed. The state and movement of water in living organisms. Academic Press, New York, pp. 205-234.

Moot DJ. 2012. An overview of dryland legume research in New Zealand. Crop and Pasture Science 63: 726-733.

Moot DJ. 2014. A review of recent research and extension on dryland lucerne in New Zealand. Proceedings of the New Zealand Society of Animal Production 74: 86-93.

Moot DJ, Anderson PVA, Anderson L, Anderson D. 2019. Animal performance changes over 11 years after implementing a lucerne grazing system on Bog Roy Station. Journal of New Zealand Grasslands 81: 75-80.

Moot DJ, Bennett SM, Mills AM, Smith MC. 2016. Optimal grazing management to achieve high yields and utilisation of dryland lucerne. Journal of New Zealand Grasslands 78: 27-34.

Moot DJ, Brown HE, Teixeira EI, Pollock KM. 2003. Crop growth and development affect seasonal priorities for lucerne management. In: DJ Moot. Ed. Legumes for Dryland Pastures. Lincoln University, New Zealand: New Zealand Grassland Association: Christchurch, pp. 201-208.
O'Connor KF. 1970. Influence of grazing management factors on herbage and animal production from lucerne pastures. Proceedings of the New Zealand Grassland Association 32: 108-116.

Palmer TP. 1982. Weeds in lucerne, why are they there, what harm do they do. In: Wynn-Williams RB. Eds. Lucerne for the 80's. Agronomy Society of New Zealand: Palmerston North, pp. 33-35

Peri PL. 2002. Leaf and canopy photosynthesis models for cocksfoot (Dactylis glomerata L.) grown in a silvopastoral system. Ph.D. Thesis, Lincoln University, Lincoln, New Zealand, 317 p.

Sheaffer CC, Tanner CB, Kirkham MB. 1988. Alfalfa water relations and irrigation. In: Hanson AA, DK Barnes \& RRJ Hill. Eds. Alfalfa and Alfalfa Improvement. American Society of Agronomy: Madison, WI, pp. 373-409.

Sim RE. 2014. Water extraction and use of seedling and established dryland lucerne crops. PhD Thesis, Lincoln University, Canterbury, New Zealand.

Sim RE, Brown HE, Teixeira EI, Moot DJ. 2017. Soil water extraction patterns of lucerne grown on stony soils. Plant and Soil 414: 95-112.

Sim RE, Moot DJ, Brown HE, Teixeira EI. 2015. Sowing date affected shoot and root biomass accumulation of lucerne during establishment and subsequent regrowth season. European Journal of Agronomy 68: 69-77.

Sinclair TR, Horie T. 1989. Leaf nitrogen, photosynthesis, and crop radiation use efficiency: a review. Crop Science 29: 90-98.

Sinclair TR. 2006. A reminder of the limitations in using Beer's law to estimate daily radiation interception of vegetation. Crop Science 46: 2343-2347.

Speedy A. 2012. The implications of spring grazing management on animal implementing gain, yield and root reserves of lucerne (Medicago sativa L.). B.Ag. Sc. (Hons) Dissertation, Lincoln University, Lincoln, New Zealand, $66 \mathrm{p}$.

Teixeira EI, Brown HE, Moot DJ, Meenken ED. 2011. Growth and phenological development patterns differ between seedling and regrowth lucerne crops (Medicago sativa L.). European Journal of Agronomy 35: 103-111.

Teixeira EI, Moot DJ, Pollock KJ, Brown HE. 2007. How does defoliation management affect yield, canopy forming processes and light interception in lucerne (Medicago sativa L.) crops? European Journal of Agronomy 27: 154-164.

White JGH. 1982. Lucerne grazing management for the 80's. In: Wynn-Williams RB. Ed. Lucerne for the 80 's. Agronomy Society of New Zealand: Palmerston North, pp. 111-114. 
